Article

\title{
What Can Rural Communities Do to Be Sustained?
}

\author{
Rachel J. C. Chen \\ Center for Sustainable Business and Development, the University of Tennessee, 311 Conference Center Building, \\ Knoxville, TN 37996-4134, USA; rchen@utk.edu; Tel.: +1-865-974-0505
}

Academic Editor: Marc A. Rosen

Received: 17 June 2016; Accepted: 8 September 2016; Published: 12 September 2016

\begin{abstract}
Since the Appalachian Regional Commission (ARC) was founded in 1965, various reports have been presented to summarize the progress in terms of economic development, strengths, weaknesses, opportunities, and threats among studied communities in the Appalachian region. The purposes of this study were to investigate (1) the condition and usage of facilities and services in the studied communities; (2) what factors contribute to local growth in improving areas; and (3) what barriers deter growth in the studied communities based on the perceptions of study participants. Ten studied counties were categorized based on their topography, demographics, and economics. Each sub-region has two selected counties (non-distressed and distressed) to represent and compare their similar topography and various stages of demographic opportunities and economic development and challenges. Location is recognized as one of the significant factors that affect communities' development. Counties perform better when they are adjacent to urban areas, own major transportation corridors, and have more supplies of natural resources than those located in more rural areas with fewer resources. This study noted the need to improve communication infrastructure (such as Internet access, broadband, and mobile communications) that impact local development opportunities and public safety.
\end{abstract}

Keywords: Appalachian Regional Commission; non-distressed and distressed

\section{Introduction}

Over the years, the Appalachian Regional Commission (ARC) has been recognized for its significant influence upon the studied region through the outcomes and assessments regarding economic improvement and provisions of strategic management and development implementations. Previous studies [1-4] have formulated a list of common factors that serve as barriers to the development of the counties, including a high number of single mothers and low levels of educational attainment. However, those counties have benefited from high levels of private land ownership, significant infrastructure investments (including Appalachian Development Highway System), and local investments in educational and health care facilities [2]. In general, when a community is near a metropolitan area, it is more likely to improve its economy.

This study aims to investigate how local governments, agencies, and community organizations plan and respond to challenging issues through surveying experiences, perceptions, and attitudes of invited community representatives toward the economic and community development efforts in ten selected counties of Appalachian regional communities. The ten counties were selected based on a list of criteria, including location, infrastructure investment, demographic factors, and economic performance. The study participants, including local residents, leaders, and stakeholders, expressed their many concerns and observations regarding their communities' strengths, weaknesses, opportunities, and threats. This paper provides a list of recommendations that reflect the experiences, attitudes, and perceptions of survey participants toward their communities' economic development progress. 


\section{Literature Review}

\subsection{Overviews of Economic Development in Appalachia}

In 1964, the President's Appalachian Regional Commission (PARC) [3] reported that per capita earnings in the Appalachian region were $35 \%$ to $44 \%$ lower than the national average, more than one-third of the region's families lived below the poverty line, and no more than one-third of the region's adults held a high school diploma. Over $25 \%$ of the region's homes needed major repairs, and approximately $75 \%$ of farm homes were considered to lack complete plumbing while $7.5 \%$ were unsafe for habitation. Almost a half century later, Appalachia's educational attainment and living conditions have demonstrated significant improvement, while its income levels still remain $20 \%$ below the national average. Notably, $100 \%$ of the region's homes now have adequate plumbing but the region still has pockets of chronic and persistent poverty through.

Over the years, many projects and committees have reported several factors that cause poverty in Appalachia such as isolated geographic locations, lack of control of resources, land tenure policies, and a variety of economic, cultural, and historical constraints [4,5]. The ARC [6] reported that geography and institutions had significant impacts on the level of economic development. ARC also recommended that local officials adopt a LEAP (Local Economic Assessment Package) while in the process of establishing strategies for community development. Communities in the Appalachian region might consider adopting more participatory tools and approaches for more effective development efforts $[7,8]$.

\subsection{Challenges in Appalachia}

The ARC has made efforts to improve economic development, infrastructure, quality of life, and public services since 1965 [4-8]. ARC concluded that geographical and historical barriers might be more persistent in the Appalachian region's distressed counties. Some communities are categorized as non-distressed counties, while others are considered distressed counties because of their lack of progress in raising incomes and making development progress. Several previous studies [9-13] focused on the distressed Appalachian sub-region such as Central Appalachia, which is dominated by the Eastern Kentucky Coal Belt. Those previous studies reported what and how low-resource communities faced barriers. For example, Sanford and Troske [14] provided insights regarding the attributes that might cause a state's low income and lower productivity such as low levels of educational attainment, the prioritization of roads over schools, a lack of innovation, and a lack of urban growth. The Brookings report [15] concluded that the state of Kentucky needed to help reduce the cost of living and indicated that many lower-income families pay a premium for some basic necessities such as housing, transportation, and food. A group of researchers from Pennsylvania State University [16] added that lacking local technical capacity was one primary issue in three cases in Kentucky (Letcher, Pike, and Floyd Counties).

\subsection{Improvement in Appalachia}

In 2011, ARC classified 96 out of 420 counties in Appalachia as distressed communities because of their below-average progress, hardship, and economic distress, although many of the counties have shown improvement over the years. Ezzell, Lambert, and Ogle [9] noted that the number of distressed counties in Appalachia has decreased by half and identified factors that made contributions to that improvement, including educational attainment, increased urbanization and industrialization.

Several previous studies [9-11] documented that there were "emerging patterns of population redistribution and migration in Appalachia" and highlighted the important roles of manufacturing, infrastructures, and educational attainment in terms of impacting regional and local economic development. For example, Black, Pollard, and Sanders [10] reported that increased income levels have led to a better level of quality of life, while many of the homes in the Appalachian region were approaching national standards in terms of having complete plumbing and heating. Lichter 
and Campbell [11] investigated regional poverty trends in terms of changing family structures on Appalachian families, concluding that welfare reform policies that focus on work forces, healthy family structures and educational improvement would bring positive long-term economic change. Halverson and Bischak [12] examined the issues of health care crisis and growth such as patterns of premature mortality, poverty, and low access to health insurance. The previous studies [13] concluded that there were correlations among physical health, mental health, level of energy, development, and productivity. Additionally, the increase in women entering the workforce, the aging of the population, and improvement in family income had contributed to the changes of the community development as well.

The uniqueness of this study lies in its investigation of the development strategies and policies at the local level, while comparing selected non-distressed counties to distressed counties within each sub-region. The ten counties were selected at the sub-regional scale based on their location and stage of economic development. Because of the micro-level discussions throughout the sub-regions, many local communities' development stories and struggles could be captured and examined. This study aimed to illustrate these real-life experiences and perceptions instead of reporting statistical annual figures through public records. The study aimed to integrate the community's endeavors into broader development needs in the future.

\section{Method}

\section{Data Collection and Sample Profile}

The purposes of this study were to investigate (1) the condition and usage of facilities and services in the studied communities; (2) what factors contribute to local growth in improving areas; and (3) what barriers deter growth in the studied communities per the perceptions of study participants. This study used three focus groups that included stakeholders (e.g., business owners), local leaders, and residents to investigate the participants' perceptions of and experiences with local efforts, policies and broad views of economic development at the community level. Each focus group included 8-12 individuals. Several principal investigators conducted onsite data collection to effectively invite a well-represented community population sample including local officials (elected officials, department heads, county or city workers, and economic development directors), business leaders (business owners, bankers and industry representatives), education and social services (school officials, extension staff, social workers, and health care representatives), and community leaders (nonprofit representatives, community activists, and minsters). Face-to-face meetings and open-ended discussions were facilitated throughout the whole process with objective input and opinions. The highlights of the focus groups presented the views of locals' perspectives and showed the reality beyond the presentations of state and/or federal statistics and/or perspectives. A comprehensive survey instrument was developed based on the outcomes of the focus group meetings in the sub-regions of Appalachia.

All individuals' identities were kept confidential, and any comments reported in the study cannot be connected to any individual participant. The members of the focus groups included representatives of both the public and private sectors. For example, members included elected leaders, education and healthcare leaders, and representatives from the business community, community volunteers, entrepreneurs, and retirees. Open opinions on local issues were freely presented by those participants. The questionnaire was distributed to 700 individuals in the studied region. In the opening instruction of this survey, a detailed explanation of the main purposes of this project was given. After removing incomplete and unusable responses, a total of 244 usable surveys were kept, resulting in a usable response rate of $34.9 \%$.

Five sub-regions were categorized based on their topography, demographics, and economics. Each sub-region has two selected counties [distressed (D) and non-distressed (ND)] to represent and compare their similar topography and various stages of demographic opportunities and economic development and challenges [9]. In the usable sample of 244 , approximately $51.2 \%$ respondents were 
from the distressed counties, and 48.8\% were from non-distressed counties. The studied counties included Greene County (Pennsylvania), Morgan County (Ohio), Pendleton County (West Virginia), Calhoun County (West Virginia), Pike County (Kentucky), Bell County (Kentucky), Avery County (North Carolina), Johnson County (Tennessee), Lawrence County (Alabama), and Noxubee County (Mississippi) (Table 1).

Table 1. Facts of Studied Counties.

\begin{tabular}{ccccc}
\hline County [Category] & State [Sub-region] & Population & Per Capita Income & Unemployment Rate \\
\hline $\begin{array}{c}\text { Greene County } \\
\text { [non-distressed] }\end{array}$ & Pennsylvania [Northern] & 38,686 & $\$ 19,832$ & $7.3 \%$ \\
\hline $\begin{array}{c}\text { Morgan County } \\
\text { [distressed] }\end{array}$ & Ohio [Northern] & 15,054 & $\$ 17,526$ & $15.2 \%$ \\
\hline $\begin{array}{c}\text { Pendleton County } \\
\text { [non-distressed] }\end{array}$ & $\begin{array}{c}\text { West Virginia } \\
\text { [North Central] }\end{array}$ & 7390 & $\$ 20,570$ & $9 \%$ \\
\hline $\begin{array}{c}\text { Calhoun County } \\
\text { [distressed] }\end{array}$ & $\begin{array}{c}\text { West Virginia } \\
\text { [North Central] }\end{array}$ & 7118 & $\$ 17,340$ & $18.3 \%$ \\
\hline $\begin{array}{c}\text { Pike County } \\
\text { [non-distressed] }\end{array}$ & Kentucky [Central] & 65,446 & $\$ 19,012$ & $8.8 \%$ \\
\hline Bell County [distressed] & Kentucky [Central] & 28,691 & $\$ 14,111$ & $15.1 \%$ \\
\hline $\begin{array}{c}\text { Avery County } \\
\text { nnon-distressed] }\end{array}$ & $\begin{array}{c}\text { North Carolina } \\
{[\text { South Central] }}\end{array}$ & 17,797 & $\$ 24,915$ & $12.6 \%$ \\
\hline $\begin{array}{c}\text { Johnson County } \\
\text { [distressed] }\end{array}$ & Tennessee [South Central] & 18,244 & $\$ 16,605$ & $10.3 \%$ \\
\hline $\begin{array}{c}\text { Lawrence County } \\
\text { [non-distressed] }\end{array}$ & Alabama [Southern] & 34,339 & $\$ 19,795$ & $16.6 \%$ \\
\hline $\begin{array}{c}\text { Noxubee County } \\
\text { [distressed] }\end{array}$ & Mississippi [Southern] & 11,631 & $\$ 13,123$ & \\
\hline
\end{tabular}

Over 700 self-administrated surveys with pre-paid postages were distributed to participating counties, resulting in 244 completed surveys with a response rate of $34.9 \%$ from 2011-2012. This study surveyed randomly selected individuals across the 5 sub-regions and two categories in the Appalachian region of the United States who were 18 years of age and older. Community feedback was analyzed by utilizing Fisher's exact test to examine differences among participants between distressed vs. non-distressed countries to find out which public service attributes have an impact on quality of life, economic status, and community development. The survey instrument was designed to investigate how technology, education, and health services impact resident experiences. Several sections of the survey asked study participants to rate (e.g., excellent, adequate, inadequate, and poor) the performance of public services in the county including county government, local government, sheriff's department, planning/zoning department, chamber of commerce, libraries, parks and recreation programs, public transportation, recycling, sewer, water, and electricity.

A list of categories (very good, good, average, poor, and very poor) was used to evaluate the overall quality of each listed attribute, including water, lakes, rivers, streams, air, forested areas, and others. Study participants were also asked to rate how likely each item was to be an opportunity for economic growth in their county. Another list of categories (very likely, somewhat likely, somewhat unlikely, and very unlikely; major problem, occasional problem, not a problem, and unsure) was used to evaluate the severity of listed obstacles, including contaminate rivers/wells, pollute air, large scale extraction, redevelopment of existing local assets, water and sewer service extensions, and people/local leadership development.

\section{Results}

The study participants were asked to describe the overall condition of services and facilities in their counties, including the state of local roads and bridges and access to health care. About $61 \%$ of 
respondents found the performance of their county government's public services to be "adequate" and $9.6 \%$ of the respondents rated the performance of their local government "excellent," while $22.5 \%$ of the respondents rated it "inadequate" and $7.1 \%$ of the respondents rated the performance of their local government "poor."

Over $85 \%$ of respondents for both distressed (D) and non-distressed (ND) counties rated the overall condition of local roads and bridges in their counties as "excellent" ( $D=1.7 \%, \mathrm{ND}=4.2 \%)$, "adequate" ( $\mathrm{D}=38 \%, \mathrm{ND}=52.1 \%)$, and "fair" ( $\mathrm{D}=46.3 \%, \mathrm{ND}=37.8 \%)$, while $14 \%$ of respondents from distressed counties gave a rank of "poor" and $6 \%$ of respondents from non-distressed counties gave a rank of "poor" to their local roads and bridges. Over 75\% of respondents for both distressed (D) and non-distressed (ND) counties rated the access to health care in their counties as "excellent" $(\mathrm{D}=2.5 \%$, $\mathrm{ND}=12.1 \%)$, "adequate" ( $\mathrm{D}=20 \%, \mathrm{ND}=33.6 \%)$, and "fair" ( $\mathrm{D}=50 \%, \mathrm{ND}=44 \%$ ), while $27.5 \%$ of respondents from distressed counties and $10.3 \%$ of respondents from non-distressed counties gave a rank of "poor" to their access to health care. Differences in the "describe the overall condition of local roads and bridges" $(p<0.029)$ and "access to health care in your county" $(p<0.000)$ categories for distressed and non-distressed counties were statistically significant (Table 2).

Table 2. Rating the overall condition of services and facilities.

\begin{tabular}{|c|c|c|c|}
\hline Characteristic & Distressed & Non-Distressed & Signif. \\
\hline $\begin{array}{l}\text { describe the overall condition } \\
\text { of local roads and bridges }\end{array}$ & $\begin{array}{c}\mathrm{N}=121 \\
\text { Excellent }=1.7 \% \\
\text { Adequate }=38 \% \\
\text { Fair }=46.3 \% \\
\text { Poor }=14 \%\end{array}$ & $\begin{array}{c}\mathrm{N}=119 \\
\text { Excellent }=4.2 \% \\
\text { Adequate }=52.1 \% \\
\text { Fair }=37.8 \% \\
\text { Poor }=5.9 \%\end{array}$ & $0.029^{* *}$ \\
\hline $\begin{array}{l}\text { access to health care in } \\
\text { your county }\end{array}$ & $\begin{array}{c}\mathrm{N}=120 \\
\text { Excellent }=2.5 \% \\
\text { Adequate }=20 \% \\
\text { Fair }=50 \% \\
\text { Poor }=27.5 \%\end{array}$ & $\begin{array}{c}\mathrm{N}=116 \\
\text { Excellent }=12.1 \% \\
\text { Adequate }=33.6 \% \\
\text { Fair }=44 \% \\
\text { Poor }=10.3 \%\end{array}$ & $0.000^{* * *}$ \\
\hline
\end{tabular}

${ }^{* * *}=$ Significant at the 0.01 level; ${ }^{* *}=$ Significant at the 0.05 level; ${ }^{*}=$ Significant at the 0.1 level; Signf. $=$ Significant level. Fisher's exact test.

When combining "sometimes" and "frequently", nearly 50\% of respondents from distressed counties and $63 \%$ of respondents from non-distressed counties mentioned that they visited their counties' internet website during the last three years. Over $91 \%$ of respondents from both distressed and non-distressed counties mentioned that they have "rarely" or "never" taken part in a protest or demonstration during the last three years. Differences in the "during the last three years, how often did you visit your county's internet website" $(p<0.039)$ and "during the last three years, how often have you taken part in a protest or demonstration" $(p<0.06)$ categories for distressed and non-distressed counties were statistically significant (Table 3 ).

Nearly $46 \%$ of respondents from distressed counties agreed that the water quality of their counties has improved, compared to $33 \%$ from non-distressed counties. In terms of supporting efforts to create more jobs even if it led to lower overall wages, about $45 \%$ of respondents from both distressed and non-distressed counties agreed with this statement, while 30\% of respondents from distressed counties answered "disagree" and $28 \%$ of respondents from non-distressed counties answered "disagree". More than one-third of respondents from distressed (40\%) and non-distressed (43\%) counties agreed that they would support efforts to create more jobs even if it led to more pollution, while $29 \%$ of respondents from distressed and $32 \%$ of respondents from non-distressed counties disagreed with those efforts. The majority of respondents from both distressed (87\%) and non-distressed (64\%) counties disagreed that the local economy has improved over the past five years, while $22 \%$ of respondents from non-distressed counties agreed that the local economy has improved over the past five years. Differences in the "during the last 3 years, the water quality of the county has improved" $(p<0.014)$, 
"I would support efforts to create more jobs even if it led to lower overall wages" $(p<0.009)$, and "the local economy has improved over the past 5 years" $(p<0.000)$ categories for distressed and non-distressed counties were statistically significant (Table 4).

Table 3. Rating the overall usage and participation of services and facilities.

\begin{tabular}{|c|c|c|c|}
\hline Characteristic & Distressed & Non-Distressed & Signif. \\
\hline $\begin{array}{l}\text { the last three years, how } \\
\text { often did you visit your } \\
\text { county's internet website }\end{array}$ & $\begin{array}{c}\mathrm{N}=123 \\
\text { Frequently }=17.9 \% \\
\text { Sometimes }=30.9 \% \\
\text { Rarely }=22.8 \% \\
\text { Never }=28.5 \%\end{array}$ & $\begin{array}{c}\mathrm{N}=117 \\
\text { Frequently }=29.9 \% \\
\text { Sometimes }=32.5 \% \\
\text { Rarely }=22.2 \% \\
\text { Never }=15.4 \%\end{array}$ & $0.039 * *$ \\
\hline $\begin{array}{l}\text { during the last three } \\
\text { years, how often have } \\
\text { you taken part in a } \\
\text { protest or demonstration }\end{array}$ & $\begin{array}{c}\mathrm{N}=125 \\
\text { Frequently }=0 \% \\
\text { Sometimes }=3.2 \% \\
\text { Rarely }=20 \% \\
\text { Never }=76.8 \%\end{array}$ & $\begin{array}{c}\mathrm{N}=118 \\
\text { Frequently }=2.5 \% \\
\text { Sometimes }=5.9 \% \\
\text { Rarely }=11 \% \\
\text { Never }=80.5 \%\end{array}$ & $0.06^{*}$ \\
\hline
\end{tabular}

Table 4. Have the listed quality attributes improved?

\begin{tabular}{|c|c|c|c|}
\hline Characteristic & Distressed & Non-Distressed & Signif. \\
\hline $\begin{array}{l}\text { During the last } 3 \text { years, the water } \\
\text { quality of the county has improved }\end{array}$ & $\begin{array}{c}\mathrm{N}=125 \\
\text { Strongly A=8\% } \\
\text { Agree (A) }=37.6 \% \\
\text { Unsure }=40.8 \% \\
\text { Disagree }(\mathrm{D})=9.6 \% \\
\text { Strongly D }=4 \%\end{array}$ & $\begin{array}{c}\mathrm{N}=118 \\
\text { Strongly A=7.6\% } \\
\text { Agree }(\mathrm{A})=25.4 \% \\
\text { Unsure }=35.6 \% \\
\text { Disagree }(\mathrm{D})=18.6 \% \\
\text { Strongly } \mathrm{D}=12.7 \%\end{array}$ & $0.014^{* *}$ \\
\hline $\begin{array}{l}\text { I would support efforts to create } \\
\text { more jobs even if it led to } \\
\text { lower overall wages }\end{array}$ & $\begin{array}{c}\mathrm{N}=125 \\
\text { Strongly } \mathrm{A}=7.2 \% \\
\text { Agree }(\mathrm{A})=38.4 \% \\
\text { Unsure }=24.8 \% \\
\text { Disagree }(\mathrm{D})=25.6 \% \\
\text { Strongly D }=4 \%\end{array}$ & $\begin{array}{c}\mathrm{N}=118 \\
\text { Strongly A= }=4.2 \% \\
\text { Agree }(\mathrm{A})=40.7 \% \\
\text { Unsure }=37.3 \% \\
\text { Disagree }(\mathrm{D})=10.2 \% \\
\text { Strongly } \mathrm{D}=7.6 \%\end{array}$ & $0.009^{* *}$ \\
\hline $\begin{array}{c}\text { The local economy has improved } \\
\text { over the past } 5 \text { years }\end{array}$ & $\begin{array}{c}\mathrm{N}=125 \\
\text { Strongly } \mathrm{A}=0.8 \% \\
\text { Agree }(\mathrm{A})=5.6 \% \\
\text { Unsure }=6.4 \% \\
\text { Disagree }(\mathrm{D})=45.6 \% \\
\text { Strongly } \mathrm{D}=41.6 \%\end{array}$ & $\begin{array}{c}\mathrm{N}=118 \\
\text { Strongly A=1.7\% } \\
\text { Agree }(\mathrm{A})=20.3 \% \\
\text { Unsure }=13.6 \% \\
\text { Disagree }(\mathrm{D})=41.5 \% \\
\text { Strongly D }=22.9 \%\end{array}$ & $0.000^{* * *}$ \\
\hline
\end{tabular}

Survey participants were also asked to rate the importance of listed attributes that impact economic development in their county, including water quality, air quality, forested areas, job opportunities, and mining. Differences in the "rate the overall quality of your county's water, lakes, rivers, and streams" $(p<0.017)$, "rate the overall quality of the air that enters your county" $(p<0.007)$, "rate the overall quality of the air that leaves your county" $(p<0.028)$, and "rate the overall quality of the forested areas in your county" $(p<0.000)$ categories for distressed and non-distressed counties were statistically significant (Table 5).

Survey participants were also asked to rate the severity of listed attributes that are obstacles to economic growth in their county, including underperforming local leaders, lack of community cooperation, burglaries, vandalism, and violent disputes. Differences in the "rate the severity of dump sites that contaminate rivers or wells impacts in your county" $(p<0.006)$, "rate the severity of industries that pollute air or water impacts in your county" $(p<0.000)$, and "rate the severity of mining or large scale extraction impacts in your county" $(p<0.000)$ categories for distressed and non-distressed 
counties were statistically significant (Table 6). Differences in the "how likely is underperforming local leaders an obstacle to economic growth in your county" $(p<0.029)$, "how likely is lack of community cooperation an obstacle to economic growth in your county" $(p<0.054)$, "how often do burglaries occur in your county" $(p<0.019)$, "how often do gang-related activities occur in your county" $(p<0.006)$, "how often does vandalism occur in your county" $(p<0.002)$, "how often do violent disputes occur in your county" $(p<0.026)$, and "how often does teen pregnancy occur in your county" $(p<0.001)$ categories for distressed and non-distressed counties were statistically significant (Tables 7 and 8).

Table 5. Rating the overall quality of listed attributes.

\begin{tabular}{|c|c|c|c|}
\hline Characteristic & Distressed & Non-Distressed & Signif. \\
\hline $\begin{array}{l}\text { Rate the overall quality of } \\
\text { your county's water, lakes, } \\
\text { rivers, and streams }\end{array}$ & $\begin{array}{c}\mathrm{N}=123 \\
\text { Very } \mathrm{G}=25.2 \% \\
\text { Good }(\mathrm{G})=43.9 \% \\
\text { Average }=24.4 \% \\
\text { Poor }(\mathrm{P})=4.9 \% \\
\text { Very } \mathrm{P}=1.6 \%\end{array}$ & $\begin{array}{c}\mathrm{N}=119 \\
\text { Very } \mathrm{G}=31.9 \% \\
\text { Good }(\mathrm{G})=27.7 \% \\
\text { Average }=22.7 \% \\
\text { Poor }(\mathrm{P})=10.9 \% \\
\text { Very } \mathrm{P}=6.7 \%\end{array}$ & $0.017^{* *}$ \\
\hline $\begin{array}{l}\text { Rate the overall quality of the } \\
\text { air that enters your county }\end{array}$ & $\begin{array}{c}\mathrm{N}=123 \\
\text { Very } \mathrm{G}=18.7 \% \\
\text { Good }(\mathrm{G})=43.1 \% \\
\text { Average }=33.3 \% \\
\text { Poor }(\mathrm{P})=4.9 \% \\
\text { Very } \mathrm{P}=0 \%\end{array}$ & $\begin{array}{c}\mathrm{N}=119 \\
\text { Very } \mathrm{G}=31.1 \% \\
\text { Good }(\mathrm{G})=32.8 \% \\
\text { Average }=22.7 \% \\
\text { Poor }(\mathrm{P})=10.1 \% \\
\text { Very } \mathrm{P}=3.4 \%\end{array}$ & $0.007^{* *}$ \\
\hline $\begin{array}{l}\text { Rate the overall quality of the } \\
\text { air that leaves your county }\end{array}$ & $\begin{array}{c}\mathrm{N}=123 \\
\text { Very } \mathrm{G}=22 \% \\
\text { Good }(\mathrm{G})=40.7 \% \\
\text { Average }=34.1 \% \\
\text { Poor }(\mathrm{P})=3.3 \% \\
\text { Very } \mathrm{P}=0 \%\end{array}$ & $\begin{array}{c}\mathrm{N}=119 \\
\text { Very } \mathrm{G}=32.8 \% \\
\text { Good }(\mathrm{G})=35.3 \% \\
\text { Average }=22.7 \% \\
\text { Poor }(\mathrm{P})=5.9 \% \\
\text { Very } \mathrm{P}=3.4 \%\end{array}$ & $0.028^{* *}$ \\
\hline $\begin{array}{l}\text { Rate the overall quality of the } \\
\text { forested areas in your county }\end{array}$ & $\begin{array}{c}\mathrm{N}=123 \\
\text { Very } \mathrm{G}=39.8 \% \\
\text { Good }(\mathrm{G})=51.2 \% \\
\text { Average }=8.9 \% \\
\text { Poor }(\mathrm{P})=0 \% \\
\text { Very } \mathrm{P}=0 \%\end{array}$ & $\begin{array}{c}\mathrm{N}=119 \\
\text { Very } \mathrm{G}=57.1 \% \\
\text { Good }(\mathrm{G})=25.2 \% \\
\text { Average }=13.4 \% \\
\text { Poor }(\mathrm{P})=3.4 \% \\
\text { Very } \mathrm{P}=0.8 \%\end{array}$ & $0.000^{* * *}$ \\
\hline
\end{tabular}

${ }^{* * *}=$ Significant at the 0.01 level; ${ }^{* *}=$ Significant at the 0.05 level; ${ }^{*}=$ Significant at the 0.1 level; Signf. = Significant level; Fisher's exact test.

Table 6. Rate the severity of listed attributes that are obstacles to economic growth.

\begin{tabular}{|c|c|c|c|}
\hline Characteristic & Distressed & Non-Distressed & Signif. \\
\hline $\begin{array}{l}\text { Rate the severity of dump sites that contaminate } \\
\text { rivers or wells impacts in your county }\end{array}$ & $\begin{array}{c}\mathrm{N}=123 \\
\mathrm{MP}=7.3 \% \\
\mathrm{OP}=61 \% \\
\mathrm{NaP}=24.4 \% \\
\text { Unsure }=7.3 \%\end{array}$ & $\begin{array}{c}\mathrm{N}=118 \\
\mathrm{MP}=18.6 \% \\
\mathrm{OP}=40.7 \% \\
\mathrm{NaP}=33.1 \% \\
\text { Unsure }=7.6 \%\end{array}$ & $0.006^{* *}$ \\
\hline $\begin{array}{l}\text { Rate the severity of industries that pollute air or } \\
\text { water impacts in your county }\end{array}$ & $\begin{array}{c}\mathrm{N}=123 \\
\mathrm{MP}=2.4 \% \\
\mathrm{OP}=29.3 \% \\
\mathrm{NaP}=58.5 \% \\
\text { Unsure }=9.8 \%\end{array}$ & $\begin{array}{c}\mathrm{N}=118 \\
\mathrm{MP}=18.6 \% \\
\mathrm{OP}=27.1 \% \\
\mathrm{NaP}=49.2 \% \\
\text { Unsure }=5.1 \%\end{array}$ & $0.000^{* * *}$ \\
\hline $\begin{array}{l}\text { Rate the severity of mining or large scale } \\
\text { extraction impacts in your county }\end{array}$ & $\begin{array}{c}\mathrm{N}=122 \\
\mathrm{MP}=9 \% \\
\mathrm{OP}=23 \% \\
\mathrm{NaP}=57.4 \% \\
\text { Unsure }=10.7 \%\end{array}$ & $\begin{array}{c}\mathrm{N}=117 \\
\mathrm{MP}=29.1 \% \\
\mathrm{OP}=17.1 \% \\
\mathrm{NaP}=47 \% \\
\text { Unsure }=6.8 \%\end{array}$ & $0.000^{* * *}$ \\
\hline
\end{tabular}

MP = Major Problem; OP = Occasional Problem; NaP = Not A Problem; ${ }^{* * *}=$ Significant at the 0.01 level; ${ }^{* *}=$ Significant at the 0.05 level; ${ }^{*}=$ Significant at the 0.1 level; Signf. = Significant level; Fisher's exact test. 
Table 7. Rate how likely the listed attributes are obstacles to economic growth.

\begin{tabular}{|c|c|c|c|}
\hline Characteristic & Distressed & Non-Distressed & Signif. \\
\hline $\begin{array}{l}\text { how likely is underperforming } \\
\text { local leaders an obstacle to } \\
\text { economic growth in your county }\end{array}$ & $\begin{array}{c}\mathrm{N}=124 \\
\mathrm{VL}=58.1 \% \\
\mathrm{SL}=41.1 \% \\
\text { Unsure }=8.1 \% \\
\mathrm{SUL}=7.3 \% \\
\mathrm{VUL}=3.2 \%\end{array}$ & $\begin{array}{c}\mathrm{N}=117 \\
\mathrm{VL}=41.9 \% \\
\mathrm{SL}=35.9 \% \\
\text { Unsure }=11.1 \% \\
\mathrm{SUL}=20.5 \% \\
\mathrm{VUL}=1.7 \%\end{array}$ & $0.029 * *$ \\
\hline $\begin{array}{l}\text { how likely is lack of community } \\
\text { cooperation an obstacle to } \\
\text { economic growth in your county }\end{array}$ & $\begin{array}{c}\mathrm{N}=122 \\
\mathrm{VL}=25.4 \% \\
\mathrm{SL}=42.6 \% \\
\text { Unsure }=13.9 \% \\
\mathrm{SUL}=13.1 \% \\
\mathrm{VUL}=4.9 \%\end{array}$ & $\begin{array}{c}\mathrm{N}=116 \\
\mathrm{VL}=20.7 \% \\
\mathrm{SL}=33.6 \% \\
\text { Unsure }=18.1 \% \\
\mathrm{SUL}=25.9 \% \\
\mathrm{VUL}=1.7 \%\end{array}$ & 0.054 * \\
\hline
\end{tabular}

VL = Very Likely; SL = Somewhat Likely; SUL = Somewhat Unlikely; VUL = Very Unlikely; ${ }^{* * *}=$ Significant at the 0.01 level; ${ }^{* *}=$ Significant at the 0.05 level; ${ }^{*}=$ Significant at the 0.1 level; Signf. $=$ Significant level; Fisher's exact test.

Table 8. Rate how often the listed activities occur in the studied counties.

\begin{tabular}{|c|c|c|c|}
\hline Characteristic & Distressed & Non-Distressed & Signif. \\
\hline $\begin{array}{l}\text { How often do burglaries } \\
\text { occur in your county? }\end{array}$ & $\begin{array}{c}\mathrm{N}=125 \\
\mathrm{~F}=31.2 \% \\
\mathrm{~S}=50.4 \% \\
\text { Rarely }=16.8 \% \\
\text { Never }=0.8 \% \\
\text { Unsure }=0.8 \%\end{array}$ & $\begin{array}{c}\mathrm{N}=119 \\
\mathrm{~F}=18.5 \% \\
\mathrm{~S}=47.1 \% \\
\text { Rarely }=32.8 \% \\
\text { Never }=1.7 \% \\
\text { Unsure }=0 \%\end{array}$ & 0.019 * \\
\hline $\begin{array}{l}\text { How often do gang-related } \\
\text { activities occur in your county? }\end{array}$ & $\begin{array}{c}\mathrm{N}=124 \\
\mathrm{~F}=2.4 \% \\
\mathrm{~S}=14.5 \% \\
\text { Rarely }=35.5 \% \\
\text { Never }=39.5 \% \\
\text { Unsure }=8.1 \%\end{array}$ & $\begin{array}{c}\mathrm{N}=119 \\
\mathrm{~F}=0.8 \% \\
\mathrm{~S}=2.5 \% \\
\text { Rarely }=37.8 \% \\
\text { Never }=53.8 \% \\
\text { Unsure }=5 \%\end{array}$ & $0.006^{* *}$ \\
\hline $\begin{array}{l}\text { How often do vandalism } \\
\text { occur in your county? }\end{array}$ & $\begin{array}{c}\mathrm{N}=124 \\
\mathrm{~F}=25 \% \\
\mathrm{~S}=50.8 \% \\
\text { Rarely }=22.6 \% \\
\text { Never }=0.8 \% \\
\text { Unsure }=0.8 \%\end{array}$ & $\begin{array}{c}\mathrm{N}=119 \\
\mathrm{~F}=8.4 \% \\
\mathrm{~S}=50.4 \% \\
\text { Rarely }=40.3 \% \\
\text { Never }=0 \% \\
\text { Unsure }=0.8 \%\end{array}$ & $0.002 * *$ \\
\hline $\begin{array}{l}\text { How often do violent disputes } \\
\text { occur in your county? }\end{array}$ & $\begin{array}{c}\mathrm{N}=124 \\
\mathrm{~F}=21 \% \\
\mathrm{~S}=49.2 \% \\
\text { Rarely }=25 \% \\
\text { Never }=1.6 \% \\
\text { Unsure }=3.2 \%\end{array}$ & $\begin{array}{c}\mathrm{N}=118 \\
\mathrm{~F}=9.3 \% \\
\mathrm{~S}=50 \% \\
\text { Rarely }=39 \% \\
\text { Never }=0.8 \% \\
\text { Unsure }=0.8 \%\end{array}$ & $0.002^{* *}$ \\
\hline $\begin{array}{l}\text { How often does teen pregnancy } \\
\text { occur in your county? }\end{array}$ & $\begin{array}{c}\mathrm{N}=124 \\
\mathrm{~F}=62.9 \% \\
\mathrm{~S}=33.1 \% \\
\text { Rarely }=0.8 \% \\
\text { Unsure }=3.2 \%\end{array}$ & $\begin{array}{c}\mathrm{N}=119 \\
\mathrm{~F}=41.2 \% \\
\mathrm{~S}=46.2 \% \\
\text { Rarely }=8.4 \% \\
\text { Unsure }=4.2 \%\end{array}$ & $0.001^{* * *}$ \\
\hline
\end{tabular}

$\mathrm{F}=$ Frequently; Sometimes $=\mathrm{S} ;{ }^{* * *}=$ Significant at the 0.01 level; ${ }^{* *}=$ Significant at the 0.05 level; ${ }^{*}=$ Significant at the 0.1 level; Signf. $=$ Significant level; Fisher's exact test.

At the end of the survey, participants were asked to use one word to describe their county according to their own experiences. Several words were mentioned across various counties, including "beautiful," "rural," "friendly", "progressive", "poor", "backward," and "polluted." Respondents were asked about their opinions regarding their county's assets based on the county's development 
and preparedness and marketing efforts. "Coal" was the most mentioned word for many counties. Several issues related to unemployment and substance abuse are dominant and need to be solved in Appalachian communities. Mentioned issues also include modern infrastructure (broadband and mobile communications), education, housing, teen pregnancy, domestic violence, and lack of youth activities.

\section{Conclusions}

The study participants were asked to rate the overall condition and usage of services and facilities, the overall quality of listed attributes that were related to their community development, and the severity of listed attributes that were obstacles to economic growth in their counties. Respondents from distressed counties were more likely to agree that the water quality of their county has improved during the last 3 years and were more likely to have underperforming local leaders and lack of community cooperation in their counties than non-distressed counties.

Respondents from non-distressed counties were more likely to better overall ratings for the "condition of local roads and bridges" and "access to health care in their counties" than those from distressed counties. Respondents from non-distressed counties mentioned that they were more likely to visit their county's internet websites more frequently and were more likely to support efforts to create more jobs even if it led to lower overall wages than those from distressed counties. Respondents from non-distressed counties mentioned that they were more likely to agree that the local economy has improved over the past 5 years and were more likely to rank better overall quality of "water, lakes, rivers, and streams", "the air that enters their county", "the air that leaves their county", and "the forested areas in their county" than those from distressed counties. Respondents from non-distressed counties reported that they had fewer listed activities occur in their counties including "burglaries", "gang-related actives", "vandalism", "violent disputes", and "teen pregnancy" than those from distressed counties.

Based on the findings of the study, many residents of the studied counties stated that regional strategies have apparently had little effect on local growth or job generation, as several local leaders and stakeholders pointed out that certain resources were too far away from small communities. Location is recognized as a significant factor that affects communities' development. Counties perform better when they are adjacent to urban areas, own major transportation corridors, and have more supplies of natural resources than those located in more rural areas with fewer resources. Among the ten selected counties, several non-distressed counties have benefitted from aerospace investments in nearby larger towns.

This study noted the need to improve communication infrastructure (such as Internet access, broadband, and mobile communications) that has an impact on local development opportunities and public safety. Communities of the Appalachian mountain region may consider adopting more rural broadband access for developing digital infrastructure. The Central Appalachian sub-region relies on the coal mining industry, which contributes to economic value as well as issues of long-term economic diversification, environmental protection, and sustainability. Nevertheless, two non-distressed counties recognize their above-average residential and business Internet access. Persistent social barriers such as fear of change have stymied economic development efforts throughout the Appalachian region $[4,9,11]$.

Identifying existing and collaborative resources for further development of tourism services may also create a visibly welcoming and hospitable image. A few non-distressed counties are seen as leaders in entrepreneurship and small business development among the ten studied counties. Useful resources are accessible and quite notable in these leading non-distressed counties, including business management training, affordable business loans, and assistance for developing business plans.

Several non-distressed counties aim to focus on educational attainment, workforce development, youth retention, economic development, entrepreneurship, linking students to STEM (Science, Technology, Engineering, and Mathematics) and vocational training programs in order to engage youth and encourage local innovation and business ventures. All studied counties may consider developing shared government services, collaborative marketing, and development programs. All communities 
may consider emphasizing and developing youth leadership programs and encouraging youths' participation in college mentoring, planning projects, and entrepreneurship training programs. Through leveraging local assets, entrepreneurship education and training, and establishing sustainable strategies to reuse vacant industrial sites and underutilized industrial parks, remote communities need to focus on creating job opportunities, promoting tourism, and increasing government efficiency in order to build a holistic sense of community.

Regarding health care services, Pike County in Kentucky is recognized for its health care initiatives while transforming health care into a vital local economic development. Despite its isolated location, Calhoun County in West Virginia maintains its local hospital to provide services for its residents while fighting to overcome macroeconomic distress. Pendleton County in West Virginia utilizes its clinic to provide affordable dental care and health programs to ensure that this rural community stays healthy. Health care services and facilities offer many job opportunities, provide economic activities, and secure a basic of quality of life.

Tourism services provide economic activities, draw visitors to local businesses, and enhance non-locals' awareness of local attractions. Utilizing the services and facilities provided by well-trained staff and visitor centers such as knowledge, varieties of brochures, visitor guides and maps can demonstrate the communities' hospitality and boost communities' economic growth through tourism expenditures and contributions. For example, Morgan County's visitor center, located in the heart of downtown McConnelsville, is a good example of a facility that provides accessible information and hospitality. Pendleton County is notable for its rock-climbing sites and attracts new manufacturers and jobs that are complementary to rock-climbing activities.

Because of its mountainous terrain, a few non-distressed counties provide adventurous tourism opportunities such as off-road vehicle trails and whitewater rafting. Mutual collaborative partnerships among local businesses, nonprofits, state government, and industry have made investment contributions to the communities. Many counties among the ten selected communities in this study note the importance of establishing and sustaining partnerships with educational institutes, including community colleges and land grant universities, due to their useful and innovative education training and affordable assistance.

Many rural communities in the Appalachian region are exploring the possibilities of utilizing social media and social networks to promote their community development and expand their communication more effectively. Several rural communities have recognized the importance of retaining their youth and providing training and development opportunities for the next generation. Recognizing the needs and wants of the Appalachian communities, along with understanding genuine local preferences, may lead to adequate improvement in economic and social life in the studied region. Future studies may consider looking at further strengths, weaknesses, opportunities, and threats for each county and featuring advanced comparison for various segments as well. Public, private, and voluntary sectors are in need of combining their resources and energies to create visionary goals that may reform the communities and improve their image through economic diversity, effective communication, stabilized political systems, sustainable economic development, education, enriched cultural depth and efficient, and affordable health care systems for generations.

Acknowledgments: Rachel J. C. Chen would like to thank Tim Ezzell, Eric Ogle, and their team members for facilitating the project and making valuable contributions with their overall suggestion. We appreciate the participating counties and their executive members' feedback. Chen also would like to thank the reviewers for their valuable comments.

Conflicts of Interest: The author declares no conflict of interest.

\section{References}

1. Isserman, A.; Rephann, T. The Economic Effects of the Appalachian Regional Commission: An Empirical Assessment of 26 Years of Regional Development Planning. J. Am. Plan. Assoc. 1995, 61, 345-364. [CrossRef] 
2. Johnson, K.M.; Stewart, S.I. Recreation, Amenity Migration and Urban Proximity. In Amenities and Rural Development: Theory, Methods, and Public Policy; Green, G.P., Deller, S.C., Marcouiller, D.W., Eds.; Edward Elgar Publishing: Northampton, MA, USA, 2005; pp. 177-196.

3. President's Appalachian Regional Commission. Appalachia: A Report by the President's Appalachian Regional Commission. 1964. Available online: http://www.arc.gov/about/ARCAppalachiaAReport bythepresidentsAppalachianRegionalCommission1964.asp (accessed on 22 December 2013).

4. Duncan, C.M. Worlds Apart: Why Poverty Persists in Rural America; Yale University Press: New Haven, CT, USA, 2014.

5. Ulrich, J.D. Southeastern Kentuckians Remain Optimistic Through Great Recession: Growing Concerns about Sprawl, Housing, and Recreational Opportunities; The Carsey Institute, University of New Hampshire: Durham, NH, USA, 2011.

6. Appalachian Regional Commission. Appalachian Region Income Report. 2009. Available online: http: //www.arc.gov/images/appregion/AppalachianIncomeReport2009\%282007Data\%29.pdf (accessed on 15 January 2014).

7. Davis, A.F.; Maurer, R.; Allen, J.E.; Talbert, J.; Childress, M. Program Evaluation of the Appalachian Regional Commission's Health Projects, 2004-2010. 2015. Available online: http:/ /www.arc.gov/assets/research_ reports/ProgramEvaluationofARCsHealthProjects2004-2010.pdf (accessed on 25 May 2016).

8. Lawrence, S.; Oliver, Z.; Hogan, M.; VanLear, S.; Baller, J.; Horrigan, J.; Johnson, M.; Patterson, J.S.; Stelfox, A.; Watts, D. Program Evaluation of the Appalachian Regional Commission's Telecommunications and Technology Projects: FY 2004-FY 2010. 2015. Available online: http:/ /www.arc.gov/assets/research_ reports/ProgramEvaluationofARCTelecommunicationsandTechnologyProjectsFY2004-2010.pdf (accessed on 15 May 2016).

9. Ezzell, T.; Lambert, D.; Ogle, E. Strategies for Economic Improvement in Appalachia's Distressed Rural Counties: An analysis of ten distressed and formerly distressed Appalachian counties. Prepared for the Appalachian Regional Commission, 2012. Available online: http://www.arc.gov/assets/research_ reports/strategiesforeconomicimprovementinappalachiasdistressedruralcounties21.pdf (accessed on 12 December 2013).

10. Dan, A.B.; Kelvin, M.P.; Seth, G.S. The Upskilling of Appalachia: Earnings and the Improvement of Skill Levels, 1960 to 2000. Prepared for the Appalachian Regional Commission, 2007. Available online: http: / / www.arc.gov/research/researchreportdetails.asp?REPORT_ID=13 (accessed on 22 March 2014).

11. Daniel, T.L.; Lori, A.C. Changing Patterns of Poverty and Spatial Inequality in Appalachia. Prepared for the Appalachian Regional Commission, 2005. Available online: http://www.arc.gov/research/ researchreportdetails.asp?REPORT_ID=75 (accessed on 25 March 2014).

12. Joel, A.H.; Greg, B. Underlying Socioeconomic Factors Influencing Health Disparities in the Appalachian Region. Prepared for the Appalachian Regional Commission, 2008. Available online: http:/ /www.arc.gov/ research/researchreportdetails.asp?REPORT_ID=9 (accessed on 2 April 2014).

13. Crabtree, S. Appalachia: America's Low Energy Zone. The Gallup Organization, 2011. Available online: http: / /www.gallup.com/poll/148787/Appalachia-America-Low-Energy-Zone.aspx (accessed on 26 May 2014).

14. Sanford, K.; Troske, K. Why is Kentucky so Poor: A Look at the Factors Affecting Cross-State Differences in Income. Center for Business and Economic Research: Kentucky Annual Economic Report, 2008. Available online: http:/ / cber.uky.edu/Downloads/Sanford\&Troske07.pdf (accessed on 20 March 2014).

15. The Brookings Institution Metropolitan Policy Program. The High Price of Being Poor in Kentucky: How to Put the Market to Work for Kentucky's Lower-Income Families. Prepared for the Annie E. Casey Foundation, 2007. Available online: http://www.brookings.edu/ /media/research/files/reports/2007/6/ metropolitanpolicy-fellowes/20070618_kentucky.pdf (accessed on 27 April 2015).

16. The Penn State University. Social Capital and Economic Development in Central Appalachia: Case Studies of Letcher, Pike, and Floyd Counties, Kentucky. Prepared for the Appalachian Regional Commission, 2000. Available online: http://www.arc.gov/assets/research_reports/strategiesforeconomic improvementinappalachiasdistressedruralcounties21.pdf (accessed on 25 April 2014).

(C) 2016 by the author; licensee MDPI, Basel, Switzerland. This article is an open access article distributed under the terms and conditions of the Creative Commons Attribution (CC-BY) license (http://creativecommons.org/licenses/by/4.0/). 